\title{
ЗАСТОСУВАННЯ ІНФОРМАЦЙНО-КОМУНІКАЦЙНИХ ТЕХНОЛОГІЙ У ФУНДАМЕНТАЛЬНІЙ ПІДГОТОВЦІ МАЙБУТНІХ СПЕЦАЛІСТІВ У ТЕХНІЧНИХ ВНЗ УКРАЇНИ
}

Кіяновська Н. М. Застосування інформаційно-комунікаційних технологій у фундаментальній підготовці майбутніх спеціалістів у технічних ВНЗ України.

У статті розглянуто особливості організації навчання вищої математики студентів інженерних спеціальностей технічних ВНЗ із використанням інформаційно-комунікаційних технологій. Визначено основні чинники, які необхідно враховувати для успішного розроблення й розвитку навчання вищої математики із застосуванням інформаційно-комунікаційних технологій; з'ясовано переваги та недоліки в організації такого навчання.

Ключові слова: інформаційно-комунікаційні технології (ІКТ), інформаційна технологія, новітні інформаційні технології, технологія в освіті, педагогічна технологія, технологія навчання, засоби навчання.

Кияновская Н. M. Применение информационно-коммуникационных технологий в фундаментальной подготовке будущих специалистов в технических вузах Украины.

В статье рассмотрены особенности организации обучения высшей математике студентов инженерных специальностей технических вузов с использованием информационнокоммуникационных технологий. Выделены основные факторы, которые необходимо учитывать для успешной разработки и развития обучения высшей математике с применением информационно-коммуникационных технологий; названы преимущества и недостатки в организации такого обучения.

Ключевые слова: информационно-коммуникационные технологии (ИКТ), информационная технология, новейшие информационные технологии, технология в образовании, педагогическая технология, технология обучения, средства обучения.

Kiyanovska N. M. Application of ICT in the fundamental training of future specialists in the technical university of Ukraine.

The article deals with the problems of mathematics teaching in high level education of engineering students in technical universities with using information and communication technologies. The article describes the basic factors that must be considered for successful design and development of education in higher mathematics using information and communication technologies; identified strengths and weaknesses in the organization of such training.

Key words: information and communication technologies (ICT), information technology, advanced information technology, technology in education, educational technology, technology training, training aids.

Основою інформаційного суспільства $є$ інформаційно-комунікаційні технології (IКТ), що широко використовуються задля соціально-економічного розвитку України, а також є одним із важливих складників сучасної системи освіти. Педагогічна психологія вищої школи розглядає процес навчання в комплексі інформаційно-навчальної, розвивальної і виховної його функції. Сучасні випускники повинні бути конкурентноспроможними не тільки на вітчизняному ринку праці, а й на світовому, тому система вищої освіти повинна відповідати останнім світовим вимогам, що висуваються до спеціаліста. Розв'язати цю проблему можна із використанням у процесі навчання інформаційно-комунікаційних технологій.

Аналіз останніх досліджень і публікацій показав, що для підготовки висококваліфікованого інженера-фахівця необхідно змінити технологічний складник методичної системи навчання, а саме: увести до засобів організації та підтримки навчання сучасні інформаційно-комунікаційні технології.

Розвиток та впровадження ІКТ в освіті активно досліджуються науковцями міжнародних організацій: ЮНЕСКО, ООН, Європейського Союзу, Ради Європи та інших. Цьому питанню присвячені праці таких науковців, як: С. Пейперта, М. Резніка (США); Е. Патаракіна, С. Полат, 
А. Хуторського, Б. Ярмахова, О. Ястребцева (Росія); В. Бикова, М. Жалдака, М. Згуровського, В. Кухаренко, Н. Морзе, С. Ракова (Україна) та інших дослідників.

Проблемі впровадження ІКТ у процес навчання в технічних університетах присвячені роботи К. Власенко, В. Клочка, Т. Крилової, Т. Максимової, І. Реутової, Ю. Триуса та інших.

Інформаційні технології, що базуються на використанні персональних комп'ютерів, комп'ютерних мереж і засобів зв'язку утворюють інформаційно-комунікаційні технології. Щодо загальної користі впровадження комп'ютерних («нових») інформаційних технологій (HIT) у педагогічний процес С.Новіков зазначає, що вони допоможуть підвищити якість підготовки студентів, підготовки фахівця, який володіє сучасним науковим світоглядом і досвідом емоційно-ціннісного ставлення до світу знань; використання засобів нових інформаційних технологій допомагає розв'язувати різноманітні психолого-педагогічні проблеми, зокрема формування умінь і навичок здійснення експериментально-дослідної діяльності, вибору змісту навчання, а також можливостей застосування засобів НIT як засобу навчальної, науково-дослідної та управлінської діяльності [2, с. 32].

Нині до фахівця-інженера роботодавцями висуваються серйозні вимоги, що передбачають співпрацю з творчою особистістю, здатною легко пристосовуватися та добре орієнтуватися в сучасних ринкових умовах. У зв'язку з цим перед ВНЗ постає завдання підготовити спеціалістів, які не лише спроможні виконувати вказівки, а здатні самостійно приймати рішення. Сприятиме розв'язанню цього питання впровадження в навчальний процес інформаційно-комунікаційних технологій навчання. Застосування IКТ у фундаментальній підготовці майбутніх спеціалістів у технічних ВНЗ потребує розроблення та впровадження змін у методиці викладання дисциплін. Це зумовлено тим, що викладач перестає бути єдиним джерелом отримання знань для студента: нині існує багато можливостей для самоосвіти, необхідні матеріали можна знайти в мережі Інтернет. Запам'ятовування та відтворення, характерні для традиційного навчання, втрачають актуальність. До студентів висуваються нові вимоги: вміння зіставляти, аналізувати, оцінювати, прогнозувати та планувати.

Meта статmi - розглянути особливості застосування інформаційно-комунікаційних технологій у фундаментальній підготовці майбутніх спеціалістів у технічних ВНЗ України.

Зміни в методиці підготовки майбутніх інженерів мають бути дотичними як до фундаментальних, так і до фахових дисциплін. Використання ІКТ у навчанні посилює роль методів активного пізнання.

Упровадження і поширення ІКТ сприяє підвищенню якості вищої освіти. Освітні технології у процесі розвитку стають більш універсальними, вони швидкими темпами проникають у всі дисципліни, оскільки все більше викладачів визнає потребу в підготовці фахівців, обізнаних у призначенні та можливостях ІКТ задля професійної діяльності.

Застосування ІКТ у процесі навчання надає викладачам вищої математики можливість урізноманітнити лекційні та практичні заняття, проводити демонстрації навчальних матеріалів, організовувати самостійну роботу студентів, підвищувати їхню успішність та мотивацію. Окрім того, використання різних технологій дозволяє викладачам економити час і активізувати увагу студентів під час аудиторних занять.

На нашу думку, впровадження ІКТ підсилює мотивацію до навчання і надає змогу організувати сам процес засвоєння знань у такий спосіб, щоб відбувався перехід:

- від навчання під керівництвом викладача до індивідуального навчання;

- від виконання прямих вказівок викладача до інтерактивного обміну знаннями;

- від передавання знань до набуття навичок;

- від послідовного повідомлення теоретичних навчальних матеріалів до породження питань та задач у процесі навчання, застосування матеріалів на практиці;

- від навчання виключно за програмою до навчання за освітніми потребами;

- від передачі знань у чітко відведений час до мобільного навчання;

- від методики навчання, що підходить для всіх, до особистісно зорієнтованого навчання;

- від текстових навчальних матеріалів до електронних;

- від навчання в аудиторіях до навчання в Інтернет-спільнотах;

- від навчання в університеті до навчання протягом усього життя.

Застосування IKT забезпечує здійснення навчання на високому рівні, регулювання навчальною діяльністю студентів, розвиток їхніх навчальних інтересів. Упровадження в процес 
навчання ІКТ і надання студентам інженерних спеціальностей та викладачам необхідних методичних рекомендацій щодо використання IКТ у фундаментальній підготовці забезпечить підвищення якості підготовки майбутніх інженерів у технічних ВНЗ України.

Під час застосування ІКТ у фундаментальній підготовці майбутніх інженерів доцільно зважати на такі рекомендації:

- у процесі вичення вищої математики студентами інженерних спеціальностей необхідно враховувати професійну спрямованість запропонованих IКТ, тобто запропоновані ІКТ зможуть допомогти студентам розв'язувати задачі за напрямком підготовки;

- навчальні матеріали в Інтернет-ресурсах мають постійно оновлюватися відповідно до програми навчання та напрямку підготовки студентів;

- підтримка зворотного зв'язку зі студентами має бути організованою всіма доступними засобами IКТ, з урахуванням їх розвитку.

Задля забезпечення студентів електронними навчальними матеріалами, організації та керування самостійною роботою студентів, підтримкою комунікаційних можливостей необхідно інтегрувати традиційне навчання з інформаційно-комунікаційними технологіями навчання.

Свен Тренхолм [1] зазначає, що більшість університетів сучасного інформаційного суспільства інтегрує віртуальні навчальні середовища (virtual learning environments VLE's) у свої програми вищої освіти. Ці веб-інструменти можуть бути використані для розроблення альтернативних та доповнення традиційних форм навчання і надають можливість зробити доступними інструкції для студентів, обмежені в часі або місці. Це, у свою чергу, розглядається як потенційний i ефективний засіб для розв'язання проблеми в деяких розвинених країнах, пов'язаної із зростаючим попитом на вищу освіту. Такі платформи електронного навчання забезпечують, наприклад, студентам можливість зручно отримати доступ до всіх або частини належних їм навчальних матеріалів, проходити тести, доступ до комплекту домашнього завдання, брати участь у різних індивідуальних та спільних навчальних заходах, формулювати питання викладачам або спільній групі студентів та розв'язувати проблеми.

Зазначимо основні чинники, які необхідно враховувати для успішного розроблення та розвитку навчання з вищої математики з використанням IКТ:

- Основний навчальний матеріал курсу: є найважливішим джерелом відомостей для студентів у процесі навчання. Він повинен бути розрахований на самостійне навчання, надавати студентам змогу зрозуміти всі суттєві аспекти курсу. Бажано, щоб усі ресурси були розроблені і написані однією і тією ж людиною (або проектною групою), яка розробляє всі оцінки. У зв'язку з характерними властивостями математичних знань, які зумовлюють необхідність багато зрозуміти і законспектувати студентам у процесі навчання, виникає потреба забезпечити доступ до основних матеріалів курсу в електронному форматі, зручному для друку. Ці основні навчальні матеріали можуть (і повинні) бути доповненими додатковими навчальними матеріалами і ресурсами, такими, як аплети, статті, симулятори.

- Роль Інтернет-інструкторів: констатовано педагогічну необхідність для забезпечення орієнтації, поточного керівництва і підтримки, а також безперервного та своєчасного зворотного зв'язку під час усього процесу навчання. Це керівництво має здійснюватися на основі надісланих повідомлень (наприклад, на початку кожного тижня) із чіткими інструкціями про те, який зміст і вид діяльності повинен бути виконаний найближчим часом. Під час опрацювання курсу підтримка має бути забезпечена швидкою реакцією на запитання студента в загальних форумах та електронною поштою. Такий зворотний зв'язок повинен бути своєчасним, у той же або наступний день, коли було розміщено запитання. За необхідності, має бути забезпеченою координація між різними викладачами одного і того ж курсу для забезпечення однорідності навчального процесу.

- Ефективне використання програмного забезпечення математики: важливо, щоб студенти розуміли, що математичні дисципліни забезпечують практичні знання і навички, необхідні для професійної діяльності. Такий підхід сприятиме підвищенню рівня мотивації. Наявне математичне програмне забезпечення має широкі можливості, тому йдеться не стільки про те, яке спеціальне програмне забезпечення використовувати, скільки про те, як ефективно інтегрувати його до змісту курсу навчальної програми. А яке програмне забезпечення використовувати цілком і повністю залежить від умов, уподобань і знань викладача, що мають постійно розширюватися. 
- Рейтингове оиінювання студентів: для того, щоб підтримувати мотивацію студентів до навчання, зокрема, вищої математики, необхідно організувати онлайн-перегляд поточного рейтингу студента в групі або на потоці. Пропонується поряд із теоретичним матеріалом викладати дані про поточні бали студентів, можливо впорядковані за рейтингом. Це дозволить студентам прослідкувати за своїми заборгованостями або слабкими місцями в опрацюванні певних тем і позбутися їх.

- Зручності віртуального навчального середовища: найважливіший аспект будь-якого навчального середовища є його зручність, тобто студенти та викладачі повинні відчувати себе комфортно, використовуючи певне навчальне середовище, усі основні параметри повинні бути інтуїтивно зрозумілими і легко знаходитись. Для курсів з вищої математики, як і для будь-якої іншої дисципліни, у навчальному просторі має бути забезпеченою можливість розміщувати виокремлені викладачем завдання - офіційні повідомлення від викладачів до студентів, забезпеченою можливість надсилати нотатки та вести дискусії та обговорення, що стосуються змісту курсу. Інші бажані функції навчального середовища - це наявність редактора формул $\mathrm{i}$ функція моніторингу студентської активності та продуктивності роботи.

У зв'язку з тим, що розвиток ІКТ відбувається постійно і безперервно, особливо стрімко в останні роки, необхідно враховувати це в методиці використання ІКТ у процесі навчання.

Комбінований підхід до вибору технологій для навчання студентів $є$ основою для створення зрозумілого, доступного, особистісно-орієнтованого процесу навчання, у якому студенти готові до співпраці між собою та з викладачем.

Використання служб та сервісів мережі Інтернет допомагає організувати самостійну роботу студентів.

У галузі застосування IКТ у навчанні вищої математики можна визначити такі переваги:

- гнучкість і зручність у поданні навчального матеріалу;

- мобільність, доступність до навчального матеріалу щодо часу і місця, доступність до навчання загалом;

- навчання індивідуалізовано, враховано особливості особистості студента, можливість організації індивідуальної роботи студента з викладачем за власним графіком навчання;

- адаптованість процесу навчання до студентів, до їх потреб і можливостей;

- скорочено розрив між теорією і практикою за допомогою програмного забезпечення, яке дозволяє у вищій математиці моделювати і розв'язувати реальні проблеми та приклади;

- забезпечено безперервний процес навчання: студенти отримують своєчасну інформацію про навчальний курс, свою успішність у процесі засвоєння курсу;

- прогресивна система оцінювання студентів поліпшує академічні результати студентів, а також сприяс мотивації їх навчання;

- розвиток таких рис особистості студента, як самостійність, відповідальність, мобільність;

- можливість дистанційної роботи зі студентами як індивідуально, так і колективно;

- викладач та студент стають співробітниками, викладач спонукає до самостійної роботи,

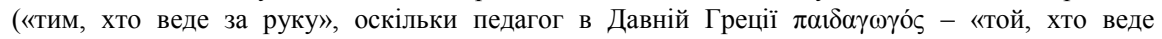
дитину»), а не управляє процесом навчання.

Однак мають місце, звичайно, і недоліки під час використання IКТ у процесі навчання вищої математики. До них можна віднести такі:

- технічні засоби не завжди працюють безвідмовно, тому можливі збої в роботі інфраструктури, що може привести до зниження ефективності навчання;

- необхідність інвестицій у розроблення та впровадження проектів, подібних до OCW;

- необхідність спеціальних знань професорсько-викладацького складу ВНЗ та час на постійне вивчення нових технологій;

- необхідність забезпечення комп'ютерами та вільним доступом до Інтернет усіх учасників навчання - викладачів та студентів;

- витрати часу на розроблення та впровадження ІКТ у процес навчання.

Та, незважаючи на наявні недоліки, переваги, які отримують учасники процесу навчання, набагато вагоміші, і тому питанню використання IКТ у процесі навчання вищої математики мають присвячуватися семінари, методичні засідання кафедр, конференції тощо задля забезпечення реалізації цієї концепції навчання, що набула поширення в усьому світі. Хоча переваги, що виявляються під час використання IКТ у процесі навчання, значуші, IКТ в 
жодному разі не можуть замінити викладача. Роль педагога залишається провідною, і лише від нього залежить якість отриманих знань студентів: від уміння зацікавити та організувати студентів, від акторської майстерності проводити заняття, якості дібраних матеріалів. Тому традиційне навчання доцільно доповнювати новітніми засобами навчання.

\section{Література}

1. Long-Term Experiences in Mathematics E-Learning in Europe and the USA / Sven Trenholm, Angel A. Juan, Jorge Simosa, Amilcar Oliveira, Teresa Oliveira // Teaching Mathematics Online: Emergent Technologies and Methodologies / Edited by Angel A. Juan, Maria A. Huertas, Sven Trenholm, Cristina Steegmann. - Hershey : Information Science Reference, 2012. - Р. 238--257. 2. Новиков С. П. Применение новых информационных технологий в образовательном процессе / С. П. Новиков // Педагогика. - 2003. -№ 9. - С. 32-38.

УДК 378.147

Олександр Коновал, Тетяна Туркот

\section{НОВІ КОНЦЕПТУАЛЬНІ ПІДХОДИ ДО ОРГАНІЗАЦІЇ САМОСТІЙНОЇ РОБОТИ СТУДЕНТІВ}

Коновал О. А., Туркот Т. І. Нові концептуальні підходи до організації самостійної роботи студентів

У статті здійснено аналіз змісту теоретико-методологічних (системного, аксіологічного, синергетичного) підходів до організації самостійної роботи студентів, обгрунтовано необхідність їх реалізації в сучасному освітньо-інформаційному середовищі вищого навчального закладу.

Ключові слова: самостійна робота студентів, системний, аксіологічний, синергетичний підходи.

Коновал А. А., Туркот Т.И. Новые концептуальные подходы к организации самостоятельной работы студентов.

В статье осуществлен анализ содержания теоретико-методологических (системного, аксиологического, синергетического) подходов к организации самостоятельной работы студентов. Обоснована необходимость их реализации в современной образовательноинформационной среде высшего учебного заведения.

Ключевые слова: самостоятельная работа студентов, системный, аксиологический, синергетический подходы.

Konoval O. A., Turkot T. I. New conceptual approaches to students' independent work organization.

The article is devoted to the analysis of the content of the theoretical and methodological (systemic, axiological, synergetic) approaches to the organization of students' independent work. The necessity of their realization in the modern educational and informational environment of higher educational establishment has been substantiated.

Key words: students' independent work; systemic, axiological, synergetic approaches.

Перехід до постіндустріального, інформаційного суспільства, докорінні економічні, політичні та соціальні зміни, що відбуваються в Україні, зумовлюють потребу підготовки нової генерації вчителів, вихователів, науково-педагогічних працівників. Цей чинник вимагає визначення концептуальних довгострокових стратегій розвитку і вдосконалення вищої освіти, системоутворювльним складником яких $є$ ідея безперервного навчання, оскільки процес формування професійних якостей і здібностей повинен відбуватися безперервно упродовж життя [8; 14]. «Програма навчання протягом життя» (Life long learning), запропонована Європейською комісією, передбачає формування восьми ключових компетенцій, якими повинен володіти кожен європеєць, серед яких обов'язковою виокремлюється навчальна компетенція як здатність та уміння навчатись [8]. У зв'язку з цим актуалізується проблема вдосконалення системи організації самостійної роботи студентів-майбутніх педагогів, яка б формувала здатність особистості до творчого саморозвитку, самоосвіти, самоактуалізації як підгрунтя інноваційної педагогічної чи науково-педагогічної діяльності. Ця тенденція є 